\title{
Dragonflies and damselflies (Odonata) from Puerto Rico: A checklist with notes on distribution and habitat
}

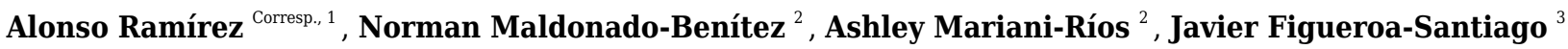 \\ ${ }^{1}$ Department of Applied Ecology, North Carolina State University, Raleigh, NC, United States \\ 2 Department of Environmental Sciences, University of Puerto Rico, San Juan, PR, Puerto Rico \\ 3 Resource Center for Science and Engineering, University of Puerto Rico, San Juan, PR, Puerto Rico \\ Corresponding Author: Alonso Ramírez \\ Email address: alonso.ramirez@ncsu.edu
}

Background. Conservation of tropical freshwater fauna requires a solid understanding of species biodiversity patterns. We provide an up to date annotated list of Odonata of Puerto Rico, which is based on current reports. The list is complemented with notes on the geographic and altitudinal distribution of this order on the island. We also compare current composition relative to early reports conducted when Puerto Rico was mostly an agricultural region.

Methods. We surveyed adult Odonata all over Puerto Rico with the aid of undergraduate students. Students were trained on capturing, preserving, and data basing specimens. All material was centralized, identified by the lead author, and deposited in the Zoology Museum at the University of Puerto Rico (MZUPR), Río Piedras campus. Surveys were complemented with focal collections by the authors and a literature review of published records for Puerto Rico and the Caribbean. We requested records from specialists to obtain the most complete list of species for the island.

Results. An annotated list of Odonata from Puerto Rico is presented, reporting 48 species distributed in two suborders and four families. We provide information on species distribution among municipalities and elevations around Puerto Rico. A historic list of species was developed for the 1930s-1940s, when agriculture covered most of Puerto Rico, based on literature and museum specimens. Both, current and historic records are similar and suggest that the Odonata fauna is dominated by generalist species and has changed little since the agricultural period. Our list provides a point of reference to understand biodiversity patterns in Puerto Rico and the Caribbean and for assessing the effects of land use change on aquatic insect diversity. 


\section{Dragonflies and damselflies (Odonata) from Puerto}

3 Rico: A checklist with notes on distribution and

4 habitat

5

6

7

Alonso Ramírez ${ }^{1}$, Norman Maldonado-Benítez ${ }^{2}$, Ashley Mariani-Ríos ${ }^{2}$, Javier Figueroa-

Santiago $^{3}$

${ }^{1}$ Department of Applied Ecology, North Carolina State University, Raleigh, North Carolina, 11 USA

2 Department of Environmental Sciences, University of Puerto Rico, Río Piedras Campus, San

13 Juan, Puerto Rico, Puerto Rico

$14{ }^{3}$ Resource Center for Science and Engineering, University of Puerto Rico, PO Box 23334, San

15 Juan, Puerto Rico, Puerto Rico

Corresponding Author:

34 Alonso Ramírez

35100 Eugene Brooks Ave, 214 David Clark Labs,

36 Raleigh, NC 27695-7617, USA

37 Email address: alonso.ramirez@ncsu.edu 
39

40

41

42

43

44

45

46

47

48

49

50

51

52

53

54

55

56

57

58

59

60

61

62

63

64

65

66

67

68

69

70

71

72

73

74

75

76

77

78

\section{Abstract}

Background. Conservation of tropical freshwater fauna requires a solid understanding of species biodiversity patterns. We provide an up to date annotated list of Odonata of Puerto Rico, which is based on current reports. The list is complemented with notes on the geographic and altitudinal distribution of this order on the island. We also compare current composition relative to early reports conducted when Puerto Rico was mostly an agricultural region.

Methods. We surveyed adult Odonata all over Puerto Rico with the aid of undergraduate students. Students were trained on capturing, preserving, and data basing specimens. All material was centralized, identified by the lead author, and deposited in the Zoology Museum at the University of Puerto Rico (MZUPR), Río Piedras campus. Surveys were complemented with focal collections by the authors and a literature review of published records for Puerto Rico and the Caribbean. We requested records from specialists to obtain the most complete list of species for the island.

Results. An annotated list of Odonata from Puerto Rico is presented, reporting 48 species distributed in two suborders and four families. We provide information on species distribution among municipalities and elevations around Puerto Rico. A historic list of species was developed for the 1930s-1940s, when agriculture covered most of Puerto Rico, based on literature and museum specimens. Both, current and historic records are similar and suggest that the Odonata fauna is dominated by generalist species and has changed little since the agricultural period. Our list provides a point of reference to understand biodiversity patterns in Puerto Rico and the Caribbean and for assessing the effects of land use change on aquatic insect diversity. 


\section{Introduction}

80

81

82

83

84

85

86

87

88

89

90

91

92

93

94

95

96

97

98

99

100

101

102

103

104

105

106

107

108

109

110

111

112

113

114

115

116

117

118

Tropical freshwater biodiversity faces a wide variety of threats, ranging from a globally changing climate to point source discharges of pollutants (Ríos-Touma \& Ramírez, 2018). The combination of these stressors is changing aquatic ecosystems, altering their function, and decreasing and homogenizing freshwater biodiversity. Understanding the effects of multiple stressors is critical for the proper management and restoration of ecosystems. Information on native biodiversity is a critical component to understand and mitigate impacts on freshwaters. Although our information on tropical diversity has increased considerable, we still have major gaps for many groups of freshwater species (e.g., aquatic dipterans and coleopterans).

Dragonflies and damselflies, order Odonata, are one the most ancient and charismatic groups of insects. There are approximately 6,338 species reported globally, but scientist agree there are many more to be discovered (Paulson \& Schorr, 2020). Adults have bright coloration, are active fliers, and relatively easy to observe in their natural habitats, making them attractive to humans, and useful in research studies (e.g., bioassessment). They are also important components of freshwater ecosystems, where they are predators. Adults consume a variety of flying insects and even spiders, while larvae consume small invertebrates and small vertebrates (e.g., fish, tadpoles). Our knowledge of Odonata diversity in the tropics is still limited, but perhaps better than that of other freshwater groups. Thus, the order could be used as indicator of how anthropogenic activities affect freshwater biodiversity (Clausnitzer et al., 2009).

Puerto Rico provides an interesting case study to understand the effects of land use changes in tropical biodiversity. Deforestation and forest conversion into agriculture followed the common pattern observed in most of the tropics. By the late $1940 \mathrm{~s}$, only $6 \%$ of the island had some sort of forest cover (Helmer, 2004). In the 1940s, Puerto Rico changed its economic model for an industrialized one, stimulating rural to urban migration, and abandonment of agriculture (Grau et al., 2003). Industrialization resulted in a steady increase in secondary forest and urbanization until the 2000s when forest cover values became stable at $40 \%$ (Grau et al., 2003). This same trend is now observed in different parts of Latin America, where forest regrowth is occurring following changes policies and economic models (Aide et al., 2013). Initial Odonata surveys in Puerto Rico were conducted during the period of intense agricultural activity, from 1930s to 1940s (Klots, 1930; García-Díaz, 1938). Thus, we have an opportunity to assess changes in freshwater biodiversity in response to increased forest cover.

In this study, we provide an up to date annotated list of Odonata of Puerto Rico based on recent reports and a survey of the island. Studies on Odonata of Puerto Rico are limited, with reports from the 1800 s and early 1900 s, during the peak in agricultural activity on the island. Klots (1932) published the first list of Odonata for the island, followed by a list by García-Díaz in 1938. Together, the two studies reported 39 species of Odonata for Puerto Rico. Sporadic 
119

120

121

122

123

124

125

126

127

128

129

130

131

132

133

134

135

136

137

138

139

140

141

142

143

144

145

146

147

148

149

150

151

152

153

154

155

156

157

158

studies that included Puerto Rico increased this number and confirmed some reports (e.g., Garrison, 1986). Meurgey (2013) reviewed early reports for the Caribbean and questioned the validity of some, including several for Puerto Rico, and decreased the number of species for the island to 36. The change was mostly due to errors in locality information provided by early collectors (Meurgey, 2013). Our goal is to provide a comprehensive list of Odonata species for Puerto Rico with notes on their distribution (e.g., municipalities, elevation). We assess changes in composition relative to early reports during the agricultural peak in Puerto Rico. Overall, we expect our study to advance our understanding freshwater biodiversity in oceanic islands and aid in understanding how land use changes affect freshwater biodiversity in the tropics.

\section{Materials \& Methods}

Puerto Rico is the smallest of the Greater Antilles in the Caribbean, with 8,900 $\mathrm{km}^{2}$ and elevations that range from sea level to $1,338 \mathrm{~m}$. The climate is tropical with a strong marine influence, thus air temperatures range from 25 to $31^{\circ} \mathrm{C}$ and precipitation from 1,000 to $4,000 \mathrm{~mm}$ per year. A dominant eastern wind interacts with the central mountain range to create a rain shadow over the southwest part of the island, where the climate is strongly seasonal and drier than the remaining of the area (Ramírez \& Gutiérrez-Fonseca, 2014).

Puerto Rico has a diversity of life zones, including subtropical moist forest, subtropical wet forest, and subtropical dry forest (Ewel \& Whitmore, 1973). The island is divided into 134 hydrological units distributed into 64 watersheds that discharge directly to the ocean, 10 of these watersheds are intermittent. In addition, there are over 70 coastal wetlands with limited water flow and strong interactions with the aquifer. The Cartagena lagoon is the only natural lake on the island, located on the southwestern side of the island (Ramírez \& Gutiérrez-Fonseca, 2014).

We surveyed adult Odonata all over Puerto Rico using two main approaches (Figure 1). The lead author has been sampling the island since 2001, conducting surveys at different locations over time. Then, during 2015-2016, with support from the Puerto Rico Louis Stokes Alliance for Minority Participation program, sponsored by the National Science Foundation, we created the Dragonfly Project (https://prlsamp.rcse.upr.edu/index.php/home/dragonfly-project). For this project, we divided the island into eight equally sized sectors and assigned a group of undergraduate students to each. Students were trained on specimen collection, handling and preservation of specimens, and data basing. We conducted two workshops per academic semester, for a total of 8 workshops during the project. Each group organized at least three sampling campaigns per semester within their designated areas. All material was centralized, identified by the lead author, and deposited in the Zoology Museum at the University of Puerto Rico (MZUPR), Río Piedras campus. Odonata surveys were complemented with a literature review of published records for Puerto Rico and the Caribbean. In addition, Rosser Garrison and Natalia von Ellenrieder were consulted to complete the list of species for the island. 
159

160

161

162

163

164

165

166

167

168

169

170

171

172

173

174

175

176

177

178

179

180

181

182

183

184

185

186

187

188

189

190

191

192

193

194

195

196

197

198
We curated and identified 154 specimens deposited in the MZUPR by Prof. Julio García Díaz. The material dated from 1935 to 1947 and was stored in paper envelopes in boxes. We used this material in combination with published reports in the literature (Klots, 1930; García-Díaz, 1938) to generate a historic list of species for Puerto Rico that coincides with the peak of agriculture in the island.

The checklist includes information on the first reliable literature record for each species. For species without published records for Puerto Rico, we provide the name of the person that first reported its occurrence.

\section{Results}

We found 49 species of Odonata in Puerto Rico, from four families (both suborders) and 29 genera (Table 1). Our team of students collected 2451 specimens around the island, resulting in 33 species. Focal sampling by the lead author resulted in eight species not collected by students. Five additional species were added based on the literature and three more based on records provided by Rosser Garrison (Table 2). Our list omits two species previously reported in the literature as present in Puerto Rico that are now considered erroneous: Ischnura capreolus (Coenagrionidae; Meurgey, 2013) and Triacanthagyna trifida (Aeshnidae; von Ellenrieder \& Garrison, 2003).

Our survey covered the main island and some of the smaller islands adjacent (e.g., Vieques, Culebra) and sampling was conducted at all elevations (Table 1). Odonata were found inhabiting all water bodies sampled (e.g., streams, ponds, lagoons, estuaries) and all land uses (e.g., forest, grasslands, urban areas; Table 1).

None of the species in our list for Puerto Rico is endemic to the island, but several are endemic to the Caribbean. Three species of Libellulidae (Erythrodiplax justiniana, Macrothemis celeno, and Scapanea frontalis) and four of Coenagrionidae (Telebasis dominicana, T. vulnerata, Lestes scalaris, and Protoneura viridis) are Caribbean endemics. Among the most abundant species of Zygoptera were Telebasis vulnerata and Ischnura ramburii (Coenagrionidae) (Figure 2) and the Anisoptera Dythemis rufinervis, Erythemis vesiculosa, and Orthemis cf. macrostigma (Libellulidae) (Figure 3).

Our list of records from the 1930s - 1940s resulted in 39 species for Puerto Rico (Table 2). The difference between lists includes some elusive species, like Tholymis citrina, and strong fliers that are often difficult to catch (e.g., Coryphaeschna viriditas). 
199 Family overview

200

201

202

203

204

\section{Aeshnidae (Suborder Anisoptera)}

205

206

This family has five genera and eight species on the island (Table 1). Collections mostly occurred at low elevations, with some specimens of Triacanthagyna collected at mid elevations

207 $(\sim 400 \mathrm{~m})$. Species in this family have large bodies and are strong fliers. We found them in all

208

209

210

211 land uses, often flying during sundown hours. The family include groups with broad distributions, like Anax, a cosmopolitan genus.

\section{Libellulidae (Suborder Anisoptera)}

This family has 15 genera and 27 species, making it the largest group on the island (Table 1).

We found them all over the island and at all elevations and land uses, but more diverse in lowlands. Erythrodiplax umbrata was the most common species in our survey, abundant in open areas. The most elusive species was perhaps Tholymis citrina, we found only one specimen in our survey. The family also included cosmopolitan species (e.g., Pantala flavescens) and Caribbean endemics (Scapanea frontalis). The introduced species Crocothemis servilia was 218 reported for Puerto Rico (Fliedner, 2009), but was not found during our survey.

The identity of Orthemis species in Puerto Rico remains unresolved. O. macrostigma has been reported for the Caribbean (Meurgey 2013) along with another morph; often call the "Antillean red" (Paulson, pers. comm.).

222

223

\section{Coenagrionidae (Suborder Zygoptera)}

224

225

226

This is the second largest family, with seven genera and 10 species (Table 1). It is well distributed around the island and in all land uses and elevations. The most common species were

228 Enallagma coecum, Ischnura hastata and I. ramburii, and Telebasis vulnerata. The latter species a Caribbean endemic.

\section{Lestidae (Suborder Zygoptera)}

233

This is the smallest family in Puerto Rico, with only three species (Table 1). Lestids specialize

234 in wetland and pond environments with abundant vegetation and might be able to deal with some 235 


\section{Discussion}

239

240

241

242

243

244

245

246

247

248

249

250

251

252

253

254

255

256

257

258

259

260

261

262

263

264

265

266

267

268

269

270

271

272

273

274

275

276

277

Our study reports the occurrence of 48 species of Odonata in Puerto Rico. We are confident that this is a good representation of the Puerto Rican fauna, as we have specimens for 41 of the species and the remaining seven had been reported by reliable sources. Previous studies reported fewer species. The earliest and most comprehensive list of species for Puerto Rico can be compiled by combining reports by Klots (1932) and García-Díaz (1938), which reported a combined total of 39 species. The next comprehensive report for Puerto Rico was published by Meurgey (2013) in his catalogue of West Indian dragonflies, but his list for Puerto Rico includes only 36 species. Our coverage was extensive and most municipalities in Puerto Rico were visited. Species were recorded from all elevations, sea level to mountains, and in all types of habitats, including coastal ecosystems (e.g., mangroves and estuaries).

The total number of species in Puerto Rico compares well with those from the remaining West Indies islands. Puerto Rico is the smallest of the Greater Antilles and its biodiversity follows the same pattern, with Cuba, Jamaica, and Hispaniola all having higher diversity than Puerto Rico (Ackerman et al., 2007). According to Meurgey (2013), Cuba has 88 species, Jamaica 58, Haiti 58, and the Dominican Republic 67. The Lesser Antilles are all much smaller in area than Puerto Rico and have fewer species, with Guadalupe as the most diverse with 38 species (Meurgey, 2013). While additional reports for Puerto Rico are possible, we do not expect many more species to be added to the current inventory of 48 species.

Puerto Rico was dominated by agricultural activities until the mid-1940s, when the island transitioned to an industrial based economy (Grau et al., 2003). Agriculture and deforestation reached a maximum in the 1940s. The increase in industry jobs resulted in the abandonment of marginal agricultural lands and eventual natural reforestation. Today, Puerto Rico is one of the few tropical locations that has gained forest, rather than suffering from deforestation (Aide et al., 2013). Earliest Odonata reports for the island were compiled during the period of maximum agriculture ( $>90 \%$ of the island). The combined list of Odonata taxa for the period is of 39 species, which is over $80 \%$ of the species currently reported. The species we are adding to that historic list include habitat generalist and strong fliers (e.g., Pantala hymenaea), with a few exceptions (e.g., Tholymis citrina). Thus, the species list of Puerto Rico today mostly reflects that of the agricultural period. This contrasts with the rest of the Greater Antilles that have species that are forest specialists and island endemics. It is possible that the size of Puerto Rico never allowed for higher diversification or that the island lost part of its fauna before we were able to document their occurrence.

Future threats to freshwater ecosystems and Odonata in Puerto Rico and the Caribbean will come with the changing climate in the region. Climate change models predict an increase in drought frequency and less overall precipitation over the Caribbean (Van Beusekom et al., 2016).

Peerj reviewing PDF | (2020:05:49270:1:1:NEW 4 Jul 2020) 
278

279

280

281

282

283

284

285

286

287

288

289

290

291

292

293

294

295

296

297

298

299

300

301

302

303

304

305

306

307

308

309

310

311

312

313

314

315

316

317

Additionally, more frequent and severe storms are expected with changing climate conditions. Conservation efforts should focus on assessing the implications of drought on habitat availability for odonates. It is also important to understand how changes in climate (e.g., precipitation, temperature) might affect different species. We provide this list as a first step toward improving our understanding and their conservation of Odonata in the island.

\section{Conclusions}

Freshwater ecosystems in the Caribbean are under strong pressure from anthropogenic activities and climate change. Our study provides based line information advancing our understanding of freshwater biodiversity in Puerto Rico, the smallest of the Greater Antilles. Our report of 48 species for the island corresponds well with it size and position in the Caribbean. In addition, it is similar to original reports from before the 1940s, indicating that Puerto Rico freshwater diversity might reflect the land use legacy of an intense agricultural period. Complete and reliable information on freshwater biodiversity is key to understand and manage aquatic ecosystems in the face of predicted changes resulting from climate change.

\section{Acknowledgements}

Our survey of Odonata in Puerto Rico was possible thanks to the support of the Puerto Rico Louis Stokes Alliance for Minority Participation and the participants of the Dragonfly Project. We also appreciate the support of Rosser Garrison and Natalia von Ellenrieder who provided literature and support for our project and Lucía Ramírez for her support in preparing the tables for the publication.

\section{References}

Ackerman JD, Trejo-Torres JC, and Crespo-Chuy Y. 2007. Orchids of the West Indies: predictability of diversity and endemism. Journal of Biogeography 34:779-786.

Aide TM, Clark ML, Grau HR, López-Carr D, Levy MA, Redo D, Bonilla-Moheno M, Riner G, Andrade-Núñez MJ, and Muñiz M. 2013. Deforestation and reforestation of Latin America and the Caribbean (2001-2010). Biotropica 45:262-271.

Clausnitzer V, Kalkman VJ, Ram M, Collen B, Baillie JEM, Bedjanič M, Darwall WRT, Dijkstra K-DB, Dow R, Hawking J, Karube H, Malikova E, Paulson D, Schütte K, Suhling F, Villanueva RJ, von Ellenrieder N, and Wilson K. 2009. Odonata enter the biodiversity crisis debate: The first global assessment of an insect group. Biological Conservation 142:1864-1869. http://dx.doi.org/10.1016/j.biocon.2009.03.028

Ewel JJ, Whitmore JL. 1973. The ecological life zones of Puerto Rico and the US Virgin Islands. USDA Forest Service, Institute of Tropical Forestry, Research Paper ITF-018. 
318 García Díaz J. 1938. An ecological survey of the fresh water insects of Puerto Rico. I. The 319 Odonata: with new life-histories. Journal of Agriculture of the University of Puerto Rico $320 \quad 22: 43-97$.

321

322

323

324

325

326

327

328

329

330

331

332

333

334

335

336

337

338

339

340

341

342

343

344

345

346

347

348

349

350

351

352

353

354

355

356

357

358

359

360

361

362

363

Garrison RW. 1986. Diceratobasis melanogaster spec. nov., a new damselfly from the Dominican Republic (Zygoptera: Coenagrionidae), with taxonomic and distribution notes on the Odonata of Hispaniola and Puerto Rico. Odonatologica 15:61-76.

Grau HR, Aide TM, Zimmerman JK, Thomlinson JR, Helmer E, and Zou X. 2003. The ecological consequences of socioeconomic and land-use changes in postagriculture Puerto Rico. BioScience 53:1159-1168.

Gundlach J. 1893. Apuntes para la fauna Puerto-Riqueña, Order Neuropteros. Anales de la Sociedad Española de Historia Natural 22: 259-314.

Helmer E. 2004. Forest conservation and land development in Puerto Rico. Landscape Ecology 19:29-40.

Klots EB. 1932. Insects of Porto Rico and the Virgin Islands- Odonata or Dragon Flies. Scientific Survey of Porto Rico and the Virgin Islands 14:1-107.

Kolbe HJ. 1888. Die geographische Verbreitung der Neuroptera und Pseudonevroptera der Antillen. Archiv fur Naturgeschichte 54:153-178.

Meurgey F. 2013. A catalogue of the West Indian dragonflies (Insecta: Odonata). Annales de la Société entomologique de France 49:298-334.

Paulson D, and Schorr M. 2020. World List of Odonata, downloadable from Slater Museum of Natural History, University of Puget Sound, Tacoma, WA 98416 (https://www.pugetsound.edu/academics/academic-resources/slater-museum/biodiversityresources/dragonflies/world-odonata-list2/)

Ramírez A, and Gutiérrez-Fonseca PE. 2014. Puerto Rico. In: Alonso-EguíaLis P, Mora JM, Campbell B, and Springer M, eds. Diversidad, conservación y uso de los macroinvertebrados dulceacuícolas de México, Centroamérica, Colombia, Cuba y Puerto Rico. Jiutepec, Morelos, México.: Instituto Mexicano de Tecnología del Agua.

Ríos-Touma B, and Ramirez A. 2018. Multiple Stressors in the Neotropical Region: Environmental Impacts in biodiversity hotspots. In: Sabater S, Elosegi A, and Ludwig R, eds. Multiple Stressors in River Ecosystems. Cambridge, MA.: Elsevier.

Van Beusekom AE, Gould WA, Terando AJ, and Collazo JA. 2016. Climate change and water resources in a tropical island system: propagation of uncertainty from statistically downscaled climate models to hydrologic models. International Journal of Climatology 36:3370-3383.

von Ellenrieder N. 2003. A synopsis of the neotropical species of 'Aeshna' Fabricus: the genus Rhionaeschna forster (Odonata: Aeshnidae). Tijdschrift voor Entomologie.

von Ellenrieder N, and Garrison RW. 2003. A synopsis of the genus Triacanthagyna (Odonata: Aeshnidae). International Journal of Odonatology 6:147-184.

Westfall MJ, Jr. 1964. A new damselfly from the West Indies (Odonata: Protoneuridae). Quarterly Journal of the Florida Academy of Sciences 27:111-119.

Wolcott GN. 1948. The Insects of Puerto Rico. Journal of Agriculture of the University of Puerto Rico 32:1-224.

PeerJ reviewing PDF | (2020:05:49270:1:1:NEW 4 Jul 2020) 


\section{Figure Legends}

366

367 Figure 1. Map of Puerto Rico showing the political boundaries of municipalities and major

368 rivers. Each dot represents a sampling location where our student teams collected specimens for 369 the survey.

370

371 Figure 2. Two abundant species of Coenagrionidae: A) Telebasis vulnerata (Photo A. Ramírez)

372 and B) Ischnura ramburii (Photo N. Maldonado-Benítez).

373

374 Figure 3. Three abundant Libellulidae: A) Dythemis rufinervis (Photo N. Maldonado-Benítez),

375 B) Erythemis vesiculosa (Photo N. Maldonado-Benítez), and C) Orthemis cf. macrostigma

376 (Photo A. Ramírez).

377 


\section{Table $\mathbf{1}$ (on next page)}

Species information: distribution and habitat

List of species for Puerto Rico with information on their occurrence: municipality, elevation range, environment sampled, and land use. 
Table 1. List of species for Puerto Rico with information on their occurrence: municipality, elevation range, environment sampled, and land use.

\begin{tabular}{|c|c|c|c|c|}
\hline Species & Municipality & Elevation & $\begin{array}{l}\text { Environment } \\
\text { sampled }\end{array}$ & Land use \\
\hline \multicolumn{5}{|l|}{ Anisoptera } \\
\hline \multicolumn{5}{|l|}{ Aeshnidae } \\
\hline \multicolumn{5}{|l|}{ Anax } \\
\hline $\begin{array}{l}\text { amazili (Burmeister, } \\
\text { 1839) }\end{array}$ & San Juan & 20 & Open area & Urban \\
\hline junius (Drury, 1773) & Cayey, Manatí, San Juan, Vega Baja & & & \\
\hline \multicolumn{5}{|l|}{ Coryphaeschna } \\
\hline adnexa (Hagen, 1861) & San Juan ${ }^{1}$ & 20 & & \\
\hline viriditas Calvert, 1952 & Boquerón ${ }^{5}$, Quebradillas & 200 & & Grassland \\
\hline \multicolumn{5}{|l|}{ Gynacantha } \\
\hline nervosa Rambur, 1842 & San Juan, Mayagüez & $2-100$ & Canal & Urban \\
\hline \multicolumn{5}{|l|}{ Rhionaeschna } \\
\hline psilus (Calvert, 1947) & Orocovis $^{2}$ & 800 & Open area & Road \\
\hline \multicolumn{5}{|l|}{ Triacanthagyna } \\
\hline $\begin{array}{l}\text { caribbea (Williamson, } \\
\text { 1923) }\end{array}$ & Mayagüez & 22 & Stream & Forest \\
\hline $\begin{array}{l}\text { septima (Selys in Sagra, } \\
1857 \text { ) }\end{array}$ & Mayagüez & 257 & Stream & Grassland \\
\hline \multicolumn{5}{|l|}{ Libellulidae } \\
\hline \multicolumn{5}{|l|}{ Brachymesia } \\
\hline furcata (Hagen, 1861) & Camuy, Juana Díaz, Ponce & $71-280$ & $\begin{array}{l}\text { Pond, Lake, } \\
\text { Reservoir }\end{array}$ & $\begin{array}{l}\text { Agriculture, } \\
\text { Grassland, Urban }\end{array}$ \\
\hline $\begin{array}{l}\text { herbida (Gundlach, } \\
\text { 1889) }\end{array}$ & $\begin{array}{l}\text { Añasco, Arecibo, Cabo Rojo, Camuy, } \\
\text { Carolina, Coamo, Fajardo, Guayanilla, } \\
\text { Juana Díaz, Ponce }\end{array}$ & $0-130$ & $\begin{array}{l}\text { Pond, Lake / } \\
\text { Reservoir, } \\
\text { Mangrove, Stream }\end{array}$ & $\begin{array}{l}\text { Agriculture, } \\
\text { Grassland, Urban }\end{array}$ \\
\hline
\end{tabular}




\section{Crocothemis}

servilia (Drury, 1773)

Yabucoa $^{3}$

$0-10$

Pond

Beach-Coastal

Dythemis

rufinervis (Burmeister Guayanilla, Juana Díaz, Lares, Las Marías, 1839) Maricao, Mayagüez, Morovis, Peñuelas, 1839)

Ponce, Río Grande, Salinas, Utuado,

$30-550$

Canal, Mangrove, Stream

Forest, Grassland,

Villalba, Yauco

\section{Erythemis}

plebeja (Burmeister, 1839)

Camuy, Coamo, Morovis, Ponce, Yauco

\section{Pond, Lake /}

Reservoir, Stream

Agriculture, Forest,

Aguadilla, Añasco, Bayamón, Camuy,

vesiculosa (Fabricius,

Carolina, Coamo, Guánica, Guayanilla,

1775)

Humacao, Isabela, Jayuya, Juana Díaz,

Mayagüez, Morovis, Ponce, Rincón, San

Canal, Open area, Pond, Stream

Agriculture, Forest, Grassland, Urban

Juan, Trujillo Alto, Yabucoa, Yauco

\section{Erythrodiplax}

berenice (Drury, 1773)

Fajardo, Ponce, Santa Isabel, Vieques, Yabucoa

justiniana (Selys in Sagra, 1857)

Adjuntas, Carolina, Guayama, Guayanilla, Isabela, Jayuya, Lares, Las Piedras, Manatí, Maunabo, Morovis, Ponce, San Juan, Yauco

Lake/Reservoir, Mangrove, River Forest, Grassland, mouth/Mangrove, Urban

Stream

Canal,

0-670 Lake/Reservoir,

Pond, Stream
Agriculture, Forest, Grassland, Urban 
umbrata (Linnaeus, 1758)

\section{Idiataphe \\ cubensis (Scudder, 1866)}

\section{Macrothemis}

celeno (Selys in Sagra, 1857)

\section{Miathyria}

marcella (Selys in Sagra, 1857)

simplex (Rambur, 1842)

\section{Micrathyria}

aequalis (Hagen, 1861)
Adjuntas, Aguada, Aguadilla, Añasco,

Arecibo, Barceloneta, Bayamón, Cabo Rojo,

Caguas, Camuy, Carolina, Cayey, Ciales,

Coamo, Corozal, Guánica, Guayama,

Guayanilla, Gurabo, Hatillo, Humacao,

Isabela, Jayuya, Juana Díaz, Lajas, Lares, Las Piedras, Loíza, Manatí, Maricao, Mayagüez, Morovis, Naguabo, Ponce, Rincón, Sabana

Grande, Salinas, San Germán, San Juan, San Sebastián, Santa Isabel, Toa Alta, Trujillo

Alto, Utuado, Vega Baja-Manatí, Yabucoa,

Yauco

\section{Manatí $^{2}$}

Adjuntas, Carolina, Ciales, Corozal,

Guayanilla, Guaynabo, Humacao, Isabela, Jayuya, Juana Díaz, Lares, Maricao,

Morovis, Peñuelas, Ponce, San Juan, Santa Isabel, Utuado, Yauco

Aguada, Arecibo, Cabo Rojo, Caguas,

Camuy, Carolina, Cidra, Juana Díaz, Lajas, Manatí, Mayagüez, Ponce, Utuado,

Yabucoa, Yauco

Manatí $^{2}$

Boquerón ${ }^{5}$, Cabo Rojo, Camuy, Carolina, Corozal, Guánica, Manatí, Ponce, Yauco
Canal, Lake/Reservoir,

0- 840 Mangrove, Open

Agriculture, Forest, Area, Pond, Stream, Wetland

\section{Grassland, Urban}

Canal,

Lake/Reservoir, Mangrove, Stream,

Wetland

Canal,

Lake/Reservoir, Open Area, Pond, Stream, Wetland

Lagoon

Lake/Reservoir, Mangrove, Pond, Stream
Agriculture, Forest, Grassland, Urban

Agriculture, Grassland, Urban

Grassland

Agriculture, Grassland, Urban 
didyma (Selys in Sagra, 1857)

dissocians Calvert, 1906

Orthemis

macrostigma (Rambur 1842)

\section{Pantala}

flavescens (Fabricius, 1798)

hymenaea (Say, 1840)

\section{Perithemis}

domitia (Drury, 1773)

\section{Scapanea}

frontalis (Burmeister, 1839)

\section{Tauriphila}

australis (Hagen, 1867)

Tholymis
Loiza, Ponce, San Juan

Aguada, Arecibo

Aguadilla, Arecibo, Cabo Rojo, Camuy, Carolina, Coamo, Fajardo, Guánica,

Guayanilla, Guaynabo, Humacao, Jayuya,

Juana Díaz, Lares, Las Piedras, Mayagüez,

Morovis, Ponce, Quebradillas, Río Grande,

San Sebastián, Santa Isabel, Utuado,

Vieques, Villalba, Yabucoa, Yauco

Aguadilla, Arecibo, Cabo Rojo, Caguas,

Camuy, Carolina, Fajardo, Guánica,

Guayanilla, Hormigueros, Humacao,

Isabela, Juana Díaz, Peñuelas, Ponce,

Salinas, San Juan, Santa Isabel, Vieques,

Yauco

Culebra

Cabo Rojo, Camuy, Carolina, Ciales, Coamo Humacao, Juana Díaz, Juncos, Lares, Las

Piedras, Manatí, Maricao, Ponce, Río

Grande, San Juan

Adjuntas, Aibonito, Guayanilla, Jayuya,

Maricao, Orocovis, Peñuelas, Ponce, Río

Grande, Utuado, Villalba, Yauco

Cidra, Lajas, Vega Baja²
Stream, Wetland

Urban

Agriculture

Canal, Estuary, Lake/Reservoir, Mangrove, Open Area, Pond, River mouth/Mangrove, Stream, Wetland

\section{Agriculture, Forest,} Grassland, Urban

Canal, Lake/Reservoir, Mangrove, Open Area, River mouth/ Mangrove, Stream, Wetland

Open area

\section{Beach}

Lake/Reservoir,

0-456 Mangrove, Pond, Stream

Forest, Grassland, Urban

Forest, Grassland, Urban

4-400 Lagoon

Grassland 


\author{
citrina (Hagen, 1867) \\ Tramea
}

abdominalis (Rambur, 1842)

binotata (Rambur, 1842)

calverti Muttkowski, 1910

insularis Hagen, 1861

onusta (Hagen, 1861)

\section{Zygoptera}

\section{CoenagRíonidae}

Enallagma

civile (Hagen, 1861)

coecum (Hagen, 1861)
San Juan

Aguadilla, Arecibo, Bayamón, Cabo Rojo,

Carolina, Coamo, Fajardo, Guayanilla,

Isabela, Juana Díaz, Mayagüez,

Quebradillas, Santa Isabel, Yabucoa, Yauco

\section{Manatí1}

Boqueron 5 , Guánica

Manatí ${ }^{2}$

Fajardo, Vieques

Arecibo, Yauco

Adjuntas, Aguada, Aguadilla, Aibonito,

Añasco, Arecibo, Barranquitas, Bayamón,

Carolina, Ciales, Coamo, Corozal, Guánica, Guayama, Guayanilla, Guaynabo,

Humacao, Jayuya, Juana Díaz, Juncos,

Lares, Las Marías, Las Piedras, Maricao,

Mayagüez, Moca, Morovis, Naguabo,

Orocovis, Patillas, Peñuelas, Ponce, Rincón,

Río Grande, Sabana Grande, San Germán,

San Juan, San Sebastián, Santa Isabel,

Utuado, Villalba, Yauco
Urban

Canal, Estuary, Lake

/ Reservoir,

Mangrove, Open

Area, Pond, Stream

Agriculture, Forest,

Grassland, Urban

Open area

Grassland

Lagoon

$0-47$

River mouth/

Mangrove

Grassland

Forest

Lake/ Reservoir Stream

Agriculture

Canal, Lake/

Reservoir,

0-750 Mangrove, Open

Forest, Grassland,

Area, Pond, Stream,

Urban 


\section{Ischnura}

\author{
Aguada, Aguadilla, Añasco, Arecibo, \\ hastata (Say, 1839) \\ Bayamón, Carolina, Guánica, Lajas, Manatí, \\ Maunabo, Moca, Ponce, San Juan, Santa \\ Isabel
}

ramburii (Selys, 1850)

\section{Leptobasis}

vacillans Hagen in Selys 1877

Boqueron ${ }^{5}$, Juncos, Moca

Aguada, Aguadilla, Aibonito, Añasco, Arecibo, Barceloneta, Bayamón, Cabo Rojo, Caguas, Camuy, Carolina, Ciales, Cidra,

Coamo, Corozal, Dorado, Fajardo, Guánica, Guayanilla, Guaynabo, Hatillo, Humacao, Isabela, Juana Díaz, Lajas, Manatí,

Mayagüez, Naguabo, Ponce, Quebradillas, Salinas, San Juan, Santa Isabel, Toa Alta, Trujillo Alto, Utuado, Vega Baja-Manatí, Vieques, Villalba, Yabucoa, Yauco

\section{Nehalennia}

minuta (Selys in Sagra, 1857)

\section{Neoerythromma}

cultellatum (Hagen in Selys, 1876)

\section{Protoneura}

viridis Westfall, 1964

\section{Moca}

Arecibo, Bayamón, Carolina, Manatí, San Juan, Yauco

Aibonito, Coamo, Guayanilla, Hatillo,

Mayagüez, Morovis, Peñuelas, Ponce, San

Germán, San Juan
Canal, Estuary,

Lake/ Reservoir,

Mangrove, Open

Area, Pond, Stream,

Agriculture, Forest,

Grassland, Urban

Wetland

Canal, Estuary,

Lake/Reservoir, Mangrove, Open Area, Pond, River mouth/ Mangrove, Stream, Wetland

Agriculture, Forest, Grassland, Urban

\section{Grassland}

Lake/ Reservoir, Mangrove, Stream

Grassland, Urban

Forest, Grassland,

Lake/Reservoir, Urban 


\title{
Telebasis
}

$\begin{array}{ll} & \begin{array}{l}\text { Aguada, Aibonito, Arecibo, Bayamón, Cabo } \\ \text { Rojo, Camuy, Carolina, Cayey, Coamo, }\end{array} \\ \text { dominicana (Selys in } & \text { Hatillo, Jayuya, Juana Díaz, Juncos, Lajas, } \\ \text { Sagra, 1857) } & \text { Manatí, Mayagüez, Moca, Naguabo, Ponce, } \\ & \text { Río Grande, San Germán, San Juan, Vega } \\ & \text { Baja-Manatí, Villalba, Yauco } \\ & \\ \text { Adjuntas, Aibonito, Barranquitas, } \\ \text { Bulnerata (Hagen, } \\ \text { Ben1) } \\ \text { Guayanilla, Guaynabo, Jayuya, Juana Díaz, } \\ \text { Juncos, Las Piedras, Maricao, Mayagüez, } \\ \text { Moca, Morovis, Naguabo, Orocovis, } \\ \text { Patillas, Peñuelas, Ponce, Río Grande, San } \\ \text { Germán, San Juan, Utuado, Vega Baja- } \\ \text { Manatí, Villalba, Yabucoa }\end{array}$

\author{
Canal, \\ Lake/Reservoir, \\ 0-1130 Mangrove, Open \\ Agriculture, Forest, \\ area, Pond, Stream, \\ Grassland, Urban \\ Wetland
}

Canal,

Lake/Reservoir,

Agriculture, Forest, Open Area, Stream, Grassland, Urban Wetland

Lagoon Grassland

forficula Rambur, 1842 Manatí

(1)

spumarius Hagen in

Selys, 1862

Arecibo, Guánica

Grassland

1- Reported by Klots (1932)

2- Rosser Garrison, personal communication

3- Reported by Fliedner (2009)

4- Reported by García Díaz (1938)

5- Dennis Paulson, personal communication 


\section{Table 2 (on next page)}

Species recorded in Puerto Rico.

Species recorded in Puerto Rico during the 1930s - 1940s, species deposited at MZUPR, and information on first reports to the island. 
1 Table 2. Species recorded in Puerto Rico during the 1930s - 1940s, species deposited at MZUPR, and 2 information on first reports to the island.

\begin{tabular}{|c|c|c|c|c|}
\hline \multirow[b]{2}{*}{ Species } & \multicolumn{2}{|c|}{$\begin{array}{l}\text { Pre- } \\
1940\end{array}$} & \multirow{2}{*}{$\begin{array}{c}\text { Specimen } \\
\text { at } \\
\text { MZUPR }\end{array}$} & \multirow{2}{*}{$\begin{array}{l}\text { First } \\
\text { report }\end{array}$} \\
\hline & $\mathrm{K}+\mathrm{GD}$ & MZUPR & & \\
\hline \multicolumn{5}{|l|}{ Anisoptera } \\
\hline \multicolumn{5}{|l|}{ Aeshnidae } \\
\hline Anax amazili & $x$ & $x$ & $x$ & García-Díaz, 1938 \\
\hline Anax junius & $x$ & $x$ & $x$ & Klots, 1932 \\
\hline Coryphaeschna adnexa & $x$ & & $x$ & Klots, 1932 \\
\hline Coryphaeschna viriditas & & & $x$ & This study \\
\hline Gynacantha nervosa & $x$ & $x$ & $x$ & Kolbe, 1888 \\
\hline Rhionaeschna psilus & & & & Von Ellenrieder , 2003 \\
\hline Triacanthagyna caribbea & & & $\mathrm{x}$ & $\begin{array}{l}\text { Von Ellenrieder \& Garrison, } \\
2003\end{array}$ \\
\hline Triacanthagyna septima & & $x$ & $x$ & $\begin{array}{l}\text { Von Ellenrieder \& Garrison, } \\
2003\end{array}$ \\
\hline \multicolumn{5}{|l|}{ Libellulidae } \\
\hline Brachymesia furcata & $x$ & & $x$ & Wolcott, 1948 \\
\hline Brachymesia herbida & $x$ & & $x$ & Klots, 1932 \\
\hline Crocothemis servilia $^{1}$ & & & & Fliedner (2009) \\
\hline Dythemis rufinervis & $x$ & $x$ & $x$ & Kolbe, 1888 \\
\hline Erythemis plebeja & $x$ & & $x$ & Klots, 1932 \\
\hline Erythemis vesiculosa & $x$ & $x$ & $x$ & Kolbe, 1888 \\
\hline Erythrodiplax berenice & $x$ & $x$ & $x$ & Klots, 1932 \\
\hline Erythrodiplax justiniana & $x$ & & $x$ & Kolbe, 1888 \\
\hline Erythrodiplax umbrata & $x$ & $x$ & $x$ & Kolbe, 1888 \\
\hline Idiataphe cubensis & $x$ & & & García-Díaz, 1938 \\
\hline Macrothemis celeno & $x$ & $x$ & $x$ & Kolbe, 1888 \\
\hline $\begin{array}{l}\text { Miathyria marcella } \\
\text { Miathyria simplex }\end{array}$ & $x$ & $x$ & $x$ & $\begin{array}{l}\text { Klots, } 1932 \\
\text { This study, R. Garrison } \\
\text { per.com. }\end{array}$ \\
\hline Micrathyria aequalis & $x$ & & $x$ & García-Díaz, 1938 \\
\hline Micrathyria didyma & $x$ & & $x$ & Kolbe, 1888 \\
\hline Micrathyria dissocians & $x$ & & $x$ & García-Díaz, 1938 \\
\hline Orthemis macrostigma & $x$ & $x$ & $x$ & Kolbe, 1888 \\
\hline Pantala flavescens & $x$ & $x$ & $x$ & Kolbe, 1888 \\
\hline Pantala hymenaea & & & & This study \\
\hline Perithemis domitia & $x$ & $x$ & $x$ & Kolbe, 1888 \\
\hline Scapanea frontalis & $x$ & $x$ & $x$ & $\begin{array}{l}\text { Klots, } 1932 \\
\text { This study, R. Garrison }\end{array}$ \\
\hline Tauriphila australis & & & $x$ & per.com. \\
\hline Tholymis citrina & & & & This study \\
\hline
\end{tabular}


Tramea abdominalis

Tramea binotata

Tramea calverti

Tramea insularis

Tramea onusta

\section{Zygoptera}

Coenagrionidae

Enallagma civile

Enallagma coecum

Ischnura hastata

Ischnura ramburii

Leptobasis vacillans

Nehalennia minuta

Neoerythromma

cultellatum

Protoneura viridis

Telebasis dominicana

Telebasis vulnerata

\section{Lestidae}

Lestes forficula

Lestes scalaris

Lestes spumarius
X

$\mathrm{X}$

$x$

$\mathrm{X}$

X

$\mathrm{X}$

$\mathrm{X}$

$x$

$\mathrm{X}$

X

$x$

$\mathrm{x}$

$x$

X

$x$
X

X

X

X

X

$x$
Kolbe, 1888

Klots, 1932

This study

This study, R. Garrison

per.com.

García-Díaz, 1938

Kolbe, 1888

Kolbe, 1888

García-Díaz, 1938

Kolbe, 1888

Kolbe, 1888

García-Díaz, 1938

García-Díaz, 1938

Westfall, 1964

García-Díaz, 1938

Gundlach 1893

Klots, 1932

Klots, 1932

Kolbe, 1888

1- Introduced species 
Figure 1

Map of Puerto Rico

Map of Puerto Rico showing the political boundaries of municipalities and major rivers. Each dot represents a sampling location where our student teams collected specimens for the survey.

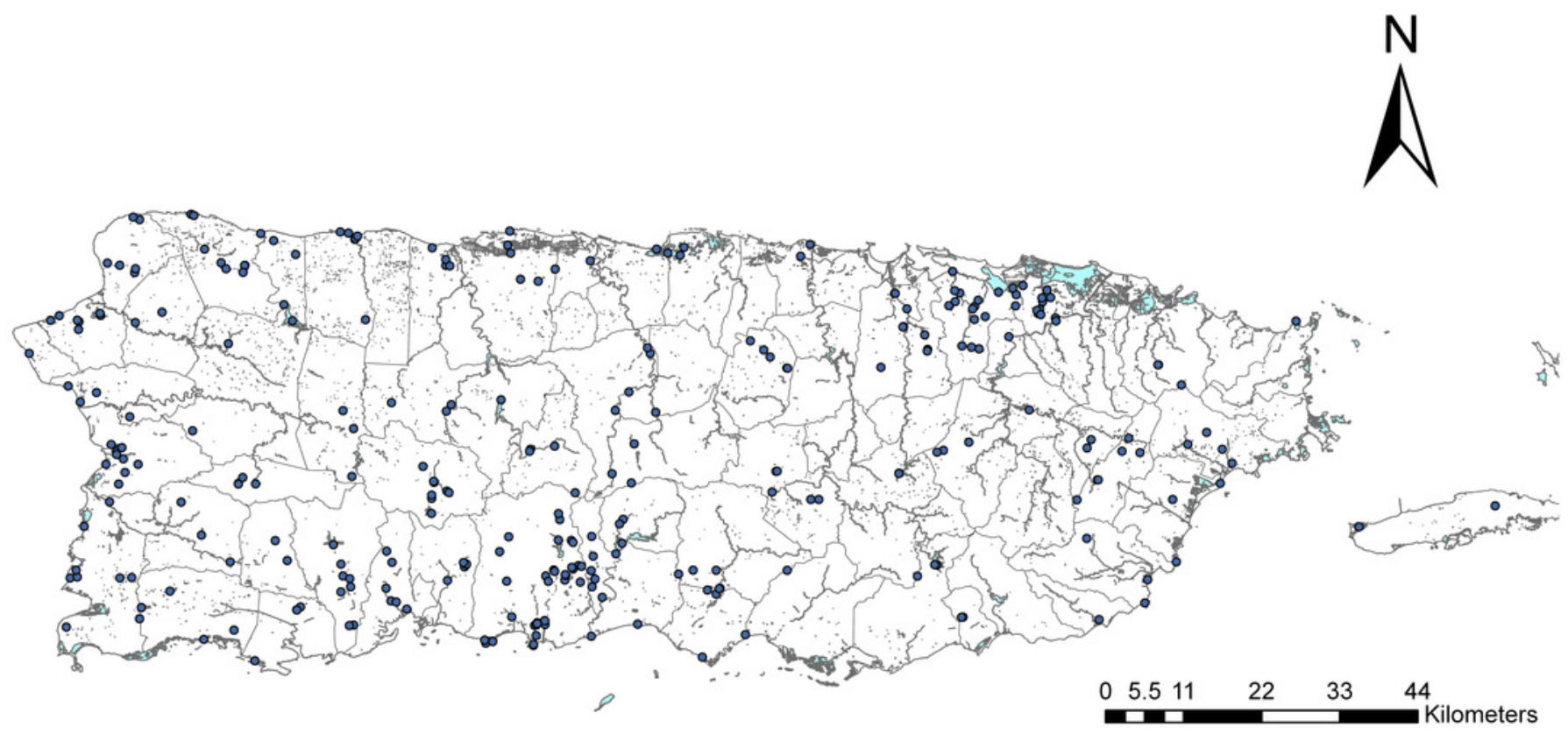


Figure 2

Common species of Zygoptera

Figure 2. Two abundant species of Coenagrionidae: A) Telebasis vulnerata (Photo Alonso

Ramírez) and B) Ischnura ramburii (Photo Norman Maldonado-Benítez). 
A)

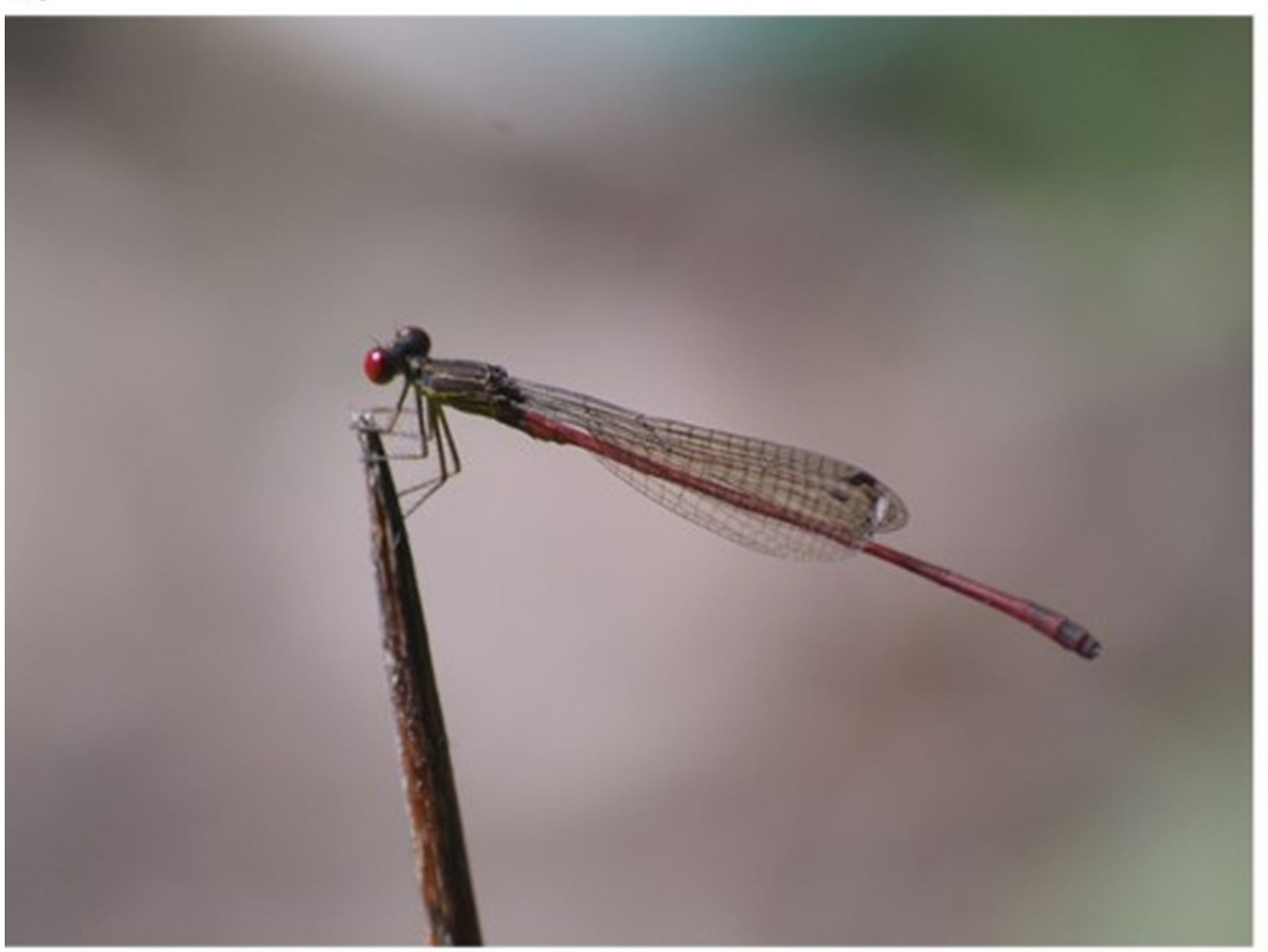

B)

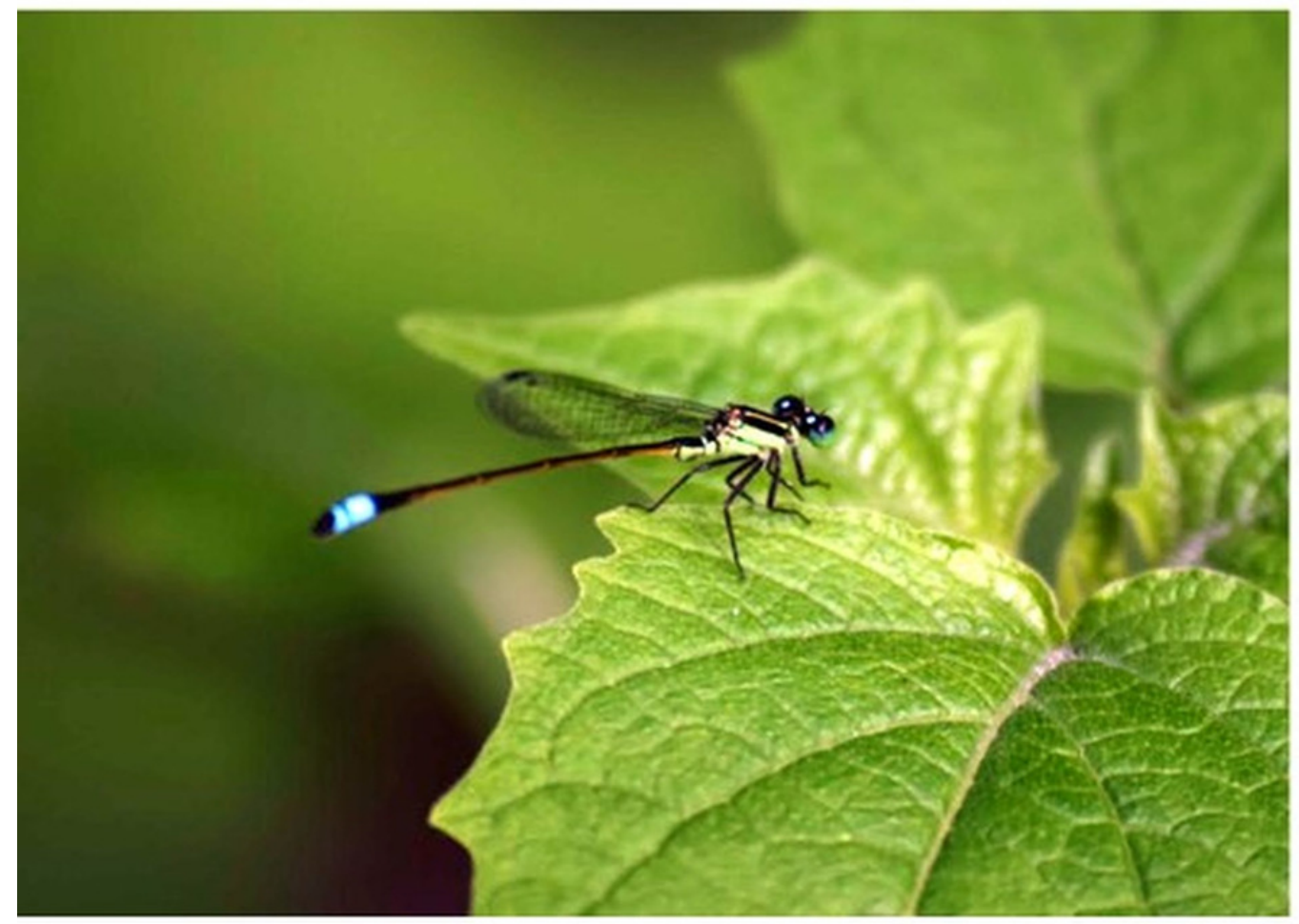


Figure 3

Common species of Anisoptera

Three abundant Libellulidae: A) Dythemis rufinervis (Photo Norman Maldonado-Benítez), B) Erythemis vesiculosa (Photo Norman Maldonado-Benítez), and C) Orthemis cf. macrostigma (Photo Alonso Ramírez). 


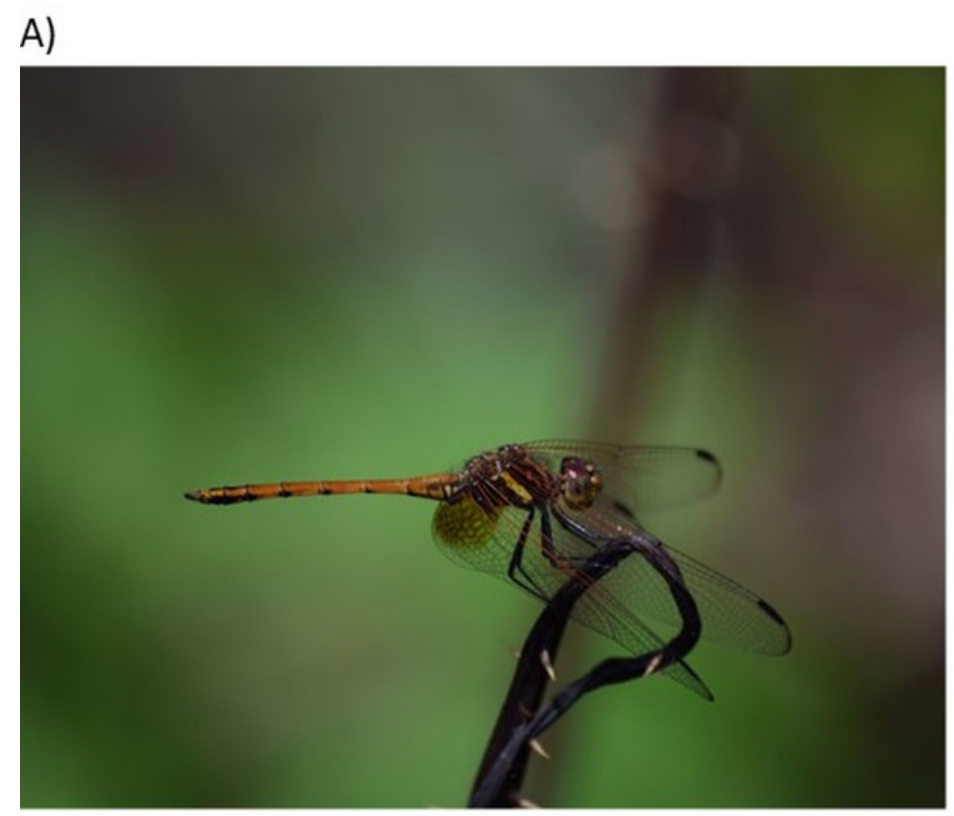

B)

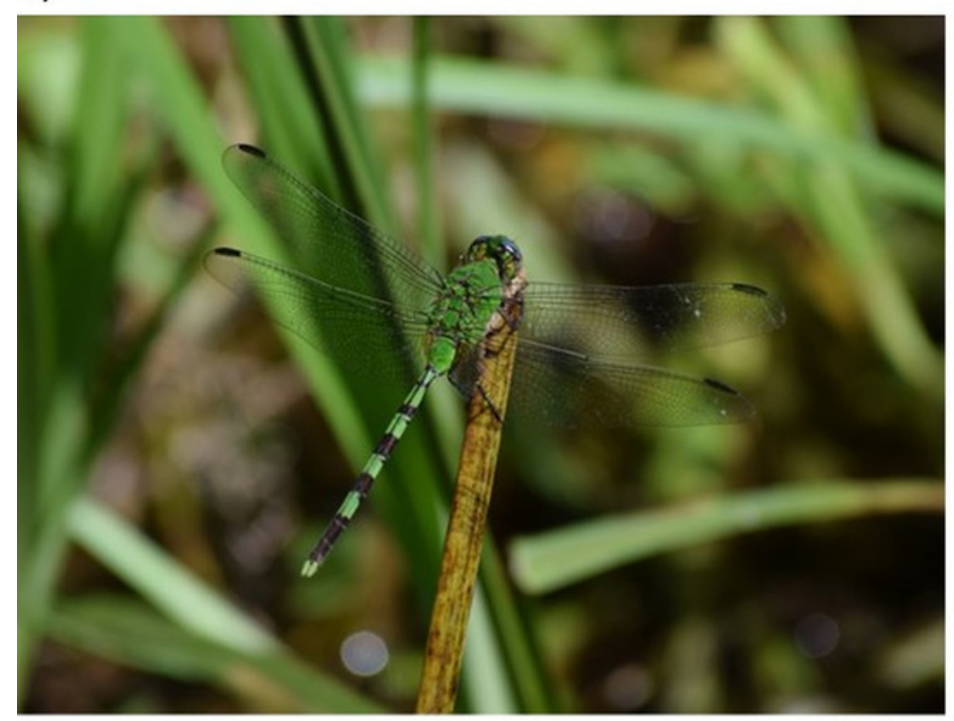

C)

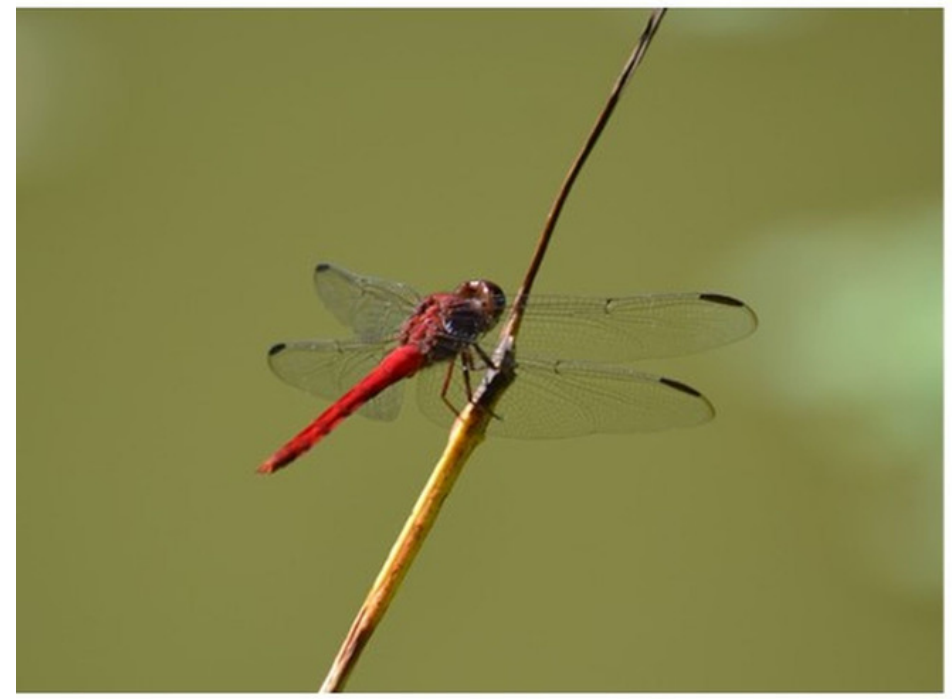

Peer) reviewing PDF | (2020:05:49270:1:1:NEW 4 Jul 2020) 